\title{
A NEW CONSIDERATION ABOUT THE ALMOPIA-PAIKON BOUNDARY BASED ON THE GEOLOGICAL MAPPING IN THE AREA OF NEROSTOMA-LAKKA (CENTRAL MACEDONIA, GREECE)
}

\author{
Tranos M. D. ${ }^{1}$, Plougarlis A. P. ${ }^{1}$, and Mountrakis D. M. ${ }^{1}$ \\ ${ }^{1}$ Aristotle University of Thessaloniki, School of Geology, Department of Geology, GR-54124 \\ Thessaloniki,Greece,tranos@geo.auth.gr,aplougar@geo.auth.gr,dmountra@geo.auth.gr
}

\begin{abstract}
Geological mapping along the boundary of Almopia and Paikon zone in the 'Nerostoma' region, NNW of Lakka village defines mafic volcanogenic rocks, meta-pelites and radiolarites, thick-bedded to massive micritic limestones and flysch meta-sediments that dip mainly towards SW. Middle-Late Cretaceous fossiliferous limestones overlie unconformably the flysch meta-sediments and are characterised only by a primary foliation $S O$ that dips at shallow angles to the NNW-N. Secondary foliations $S 1$ (sub-parallel to $S 0$ ) and $S 2$ are observed in the meta-clastic rocks. $A D 1$ event caused F1 and progressively F2 folds to which $S 2$ is the axial plane schistosity dipping to $S W$. This event which has not affected the fossiliferous limestones is related to an oblique convergence or inclined transpression during the Late Jurassic-Early Cretaceous. A D2 event dated in Early Tertiary caused an intense NE-thrusting and $S$-C cataclastic fabric defining top-to-the NE sense-of-shear. At many parts, the unconformity contact between the fossiliferous limestones and the underlying flysch is obliterated by this thrusting event. As a result, the boundary between Almopia and Paikon zones as paleo-geographically defined in this area seems to be meaningless for the Jurassic-Cretaceous times.
\end{abstract}

Key words: Internal Hellenides, Axios zone, transpression, Greece.

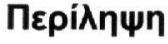

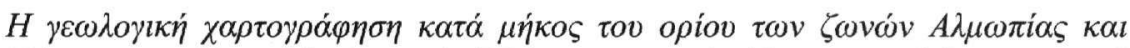

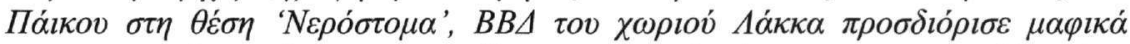

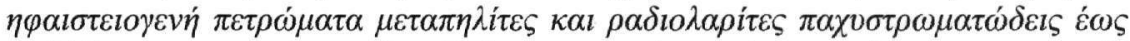

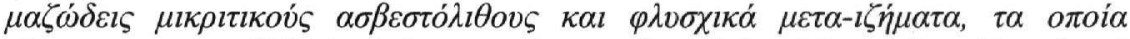

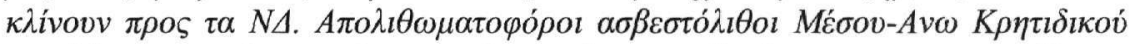

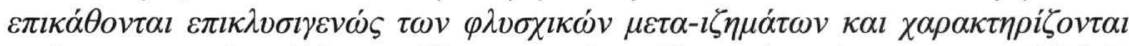

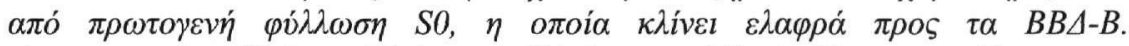

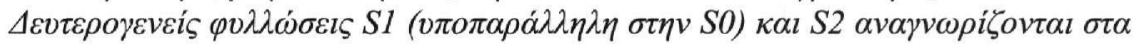

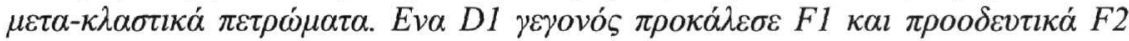

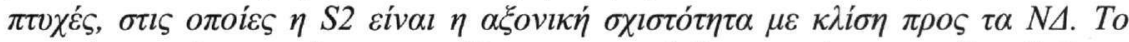

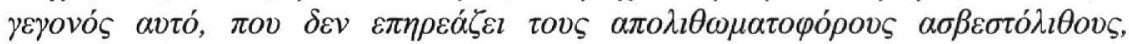

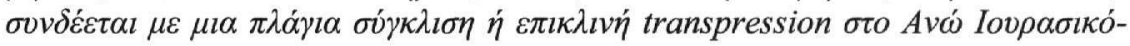




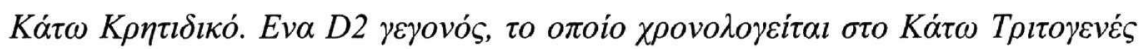

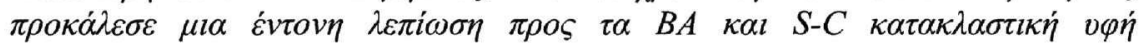

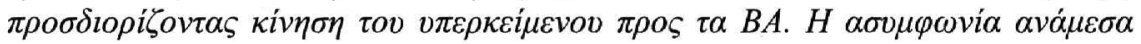

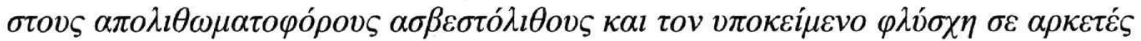

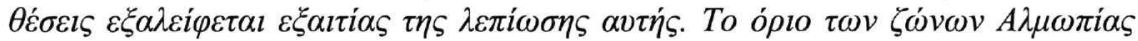

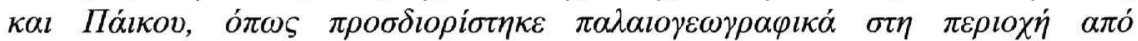

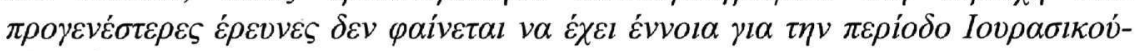

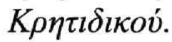

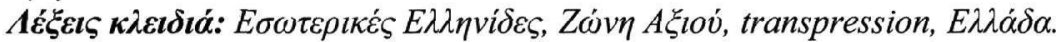

\section{Introduction}

In the Internal Hellenides, at the east of the Pelagonian zone (Fig. 1a), the Axios zone divided from east to west into the zones of Peonia, Paikon and Almopia (Mercier 1968) documents the Mesozoic-Early Cenozoic evolution of several small oceanic basins and a complex history of terrane assembly. For this reason, it has concentrated the interest of many geoscientists (Mercier 1968, Mountrakis 1979, Vergely 1984, Stais 1993, Stais and Ferriere 1994, Sharp and Robertson 1993, Brown and Robertson 1994, Vergely and Mercier 2000, Ferriere et al. 2001, Brown and Robertson 2003, etc.). As a result, several arguments and questions about the Mesozoic and Cenozoic evolution not only for the zone itself, but also for the Internal Hellenides have been raised. One of the most arguable subjects is the boundary between the Almopia and Paikon zones, since different interpretations have been given to its geometry and kinematics. In particular, this boundary had been initially interpreted as a WSW-directed thrust through which the Paikon zone overthrusted the Almopia zone (Fig. 1b) (Mercier 1968, Mercier and Vergely 1984), but later as a thrust with opposite transport direction (Fig. 1c) (Sharp and Robertson 1993, Stais 1993). In this paper, we carried out a detail geological and tectonic mapping in scale 1:5.000 in the area 'Nerostoma', which is located approximately $3 \mathrm{~km} \mathrm{NNW}$ of Lakka village (Fig. 1), with the purpose to re-examine the nature of the Almopia-Paikon boundary and its deformational history. Based on this work, we present new data about the geology of the region and redefine the boundary between the zones of Almopia and Paikon.

\section{Geological Setting}

The Almopia zone and the Peonia zone (which will not be considered in detail here) to the west and east of Paikon zone, respectively, comprise contrasting Mesozoic-Early Tertiary lithologies, including Mesozoic ophiolitic rocks, which are absent from the Paikon zone. The Almopia zone in the west is widely seen as the site of an Early Mesozoic oceanic basin termed the Almopia Ocean (Stais, 1993, Stais and Ferriere, 1991, Sharp and Robertson, 1998). It comprises many units which are characterized by various lithologies and internal thrust deformation. From these units the easternmost one, the Krania Unit, comprising volcanogenic, deep-sea sediments and flysch sediments comes in contact with rocks of the Paikon zone (Fig. 1a).

The Paikon zone (Fig. 1c) is subdivided into two main sequences (Brown and Robertson 2004): (a) The Lower Sequence that consists, from bottom to top, of metamorphosed Triassic?-Jurassic, mixed carbonate-clastic sequence (Gandatch Formation), Jurassic volcanosedimentary rocks (Livadia and Kastaneri Formations) and Lower Cretaceous flysch (Grammos Formation), (b) The Upper Sequence that consists of Cretaceous transgressive limestones that pass upwards to Upper Cretaceous buff pelagic limestones and Lower Tertiary flysch (Tsouka flysch).

The boundary of the Paikon zone with the Almopia zone as has been firstly defined by Mercier (1968) presents NNW-SSE trend from the Greek/former Yugoslavia borders as south as the Yannitsa basin, where it disappears beneath the Quaternary sediments. Close to the borders, in the Pinovo Mt., it coincides with the WSW-directed thrusting of the Upper Cretaceous limestones 

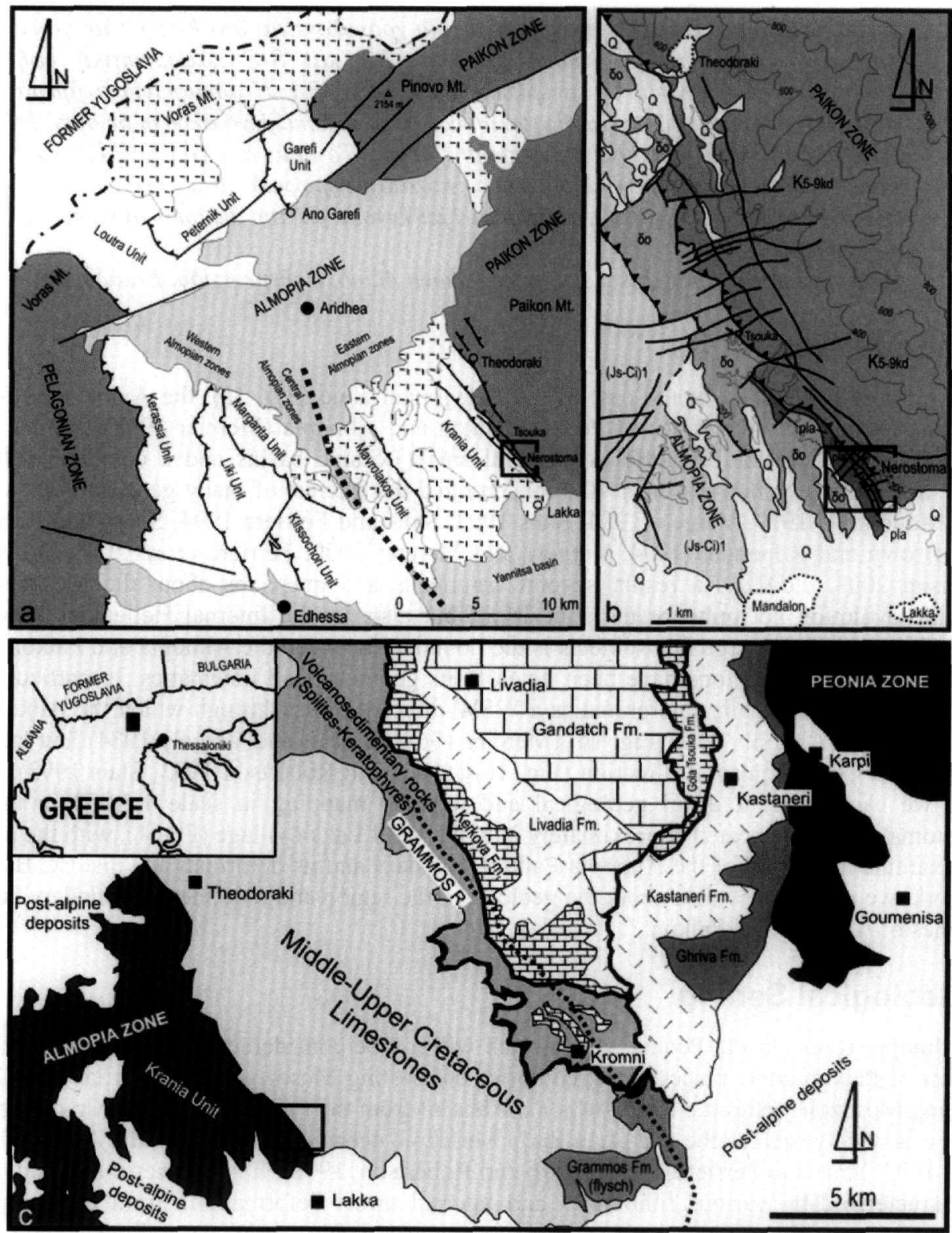

Figure 1 - General geological sketch maps of the wider study area: (a) The Almopia zone and its eastern boundary with Paikon zone (modified from Mercier 1968), (b)The AlmopiaPaikon boundary as shown in geological map Edhessa sheet, (Js-Ci)1: volcanosedimentary rocks, ठo: dolerites, pla: hyaloclastites (modified from Mercier and Vergely 1984), (c) The tectono-stratigraphic division of the Paikon zone based on previous studies (modified from Vergely et al. 2000). The study area is shown with square frame

over the Garefi ophiolitic rocks of the Almopia zone (Fig. 1a). Further to the south, the boundary is located along the western pediments of the Paikon Mt. passing through the Theodoraki village, Sharp and Robertson (1993) and Stais (1993) suggest that this boundary is a thrust with opposite transport direction through which the rocks of the Krania Unit were placed either onto the Upper Cretaceous fossiliferous limestones or their stratigraphically overlying Campanian-Maastrichtian 
flysch sediments of the Paikon zone. Since then, many different aspects concerning the boundary and the evolution of the Paikon zone have come in light.

Ricou and Godfriaux (1995) accepting Sharp and Robertson's (1993) interpretation, proposed that the Paikon Mt. is a large anticlinal tectonic window with a core of crystalline rocks from Pelagonian massif. These rocks outwards and upwards are tectonically overlain by the rocks of Paikon zone as a result of large $\mathrm{W}$-directed thrusting. This thrusting took place after the deposition of the Upper Cretaceous limestones, which in turn are tectonically overlain by Almopia and Peonia zones to the west and east, respectively, of the Paikon Mt.

A slightly different view is presented in the cross-section carried out by Ferriere et al. (2001). In particular, they show that the rocks of the Almopia zone thrust over a thin carbonate horizon ('Tsouka imbricates' of Sharp and Robertson (1993)) that belongs to the Lakka Unit of the Paikon zone. This horizon stratigraphically overlies Campanian-Maastrichtian flysch sediments. In addition, according to them, the Lakka Unit also comprises, to the bottom, Cretaceous limestones, Lower Cretaceous flysch and Jurassic volcanogenic rocks.

It is clear that Sharp and Robertson (1993) and Ferriere et al. (2001) assign a CampanianMaastrichtian age to the flysch exposed at/or close to the Almopia/Paikon boundary. However, the first authors assigned this age based on the fauna of this age found by Mercier (1968) in similar lithologies. In addition, the second authors admitted that there is a paleontological problem with the faunas and the rocks of the area, since the Globotruncanas found on the roof of the carbonate rocks assign Campanian-Maastrichtian age to these rocks, whereas the Radiolarian fossils found in the overlying flysch sediments assign Turonian or Cenomanian-Turonian or even earlier age.

The deformation of the area has been firstly described by Mercier (1968) who recognized that the Paikon massif had been folded into a broad N-S anticline in post-Upper Cretaceous times and later by Vergely (1984) who proposed three distinct deformational phases to describe the regional deformation of the area:

JE1 - Upper Jurassic: a syn-metamorphic phase of compression causing cm- to m- scale, E-W trending isoclinal folds.

JE2 - Lower Cretaceous: syn-metamorphic phase of compression with large folds $(10 \mathrm{~m}-100 \mathrm{~m})$ with ESE to E vergence.

CT1-2 - Tertiary: series of compressional phases with westward vergence.

More recently Brown and Robertson (1994) distinguished the following events:

D1: This is similar in structures and age with the JE1 of Vergely (1984) and includes E-Wtrending tight isoclinal folds with axial planar cleavage and an axis parallel intersection lineation.

E1: This is an inferred extensional event during the Cretaceous because of the hiatus observed in Cenomanian-Turonian times within the Paikon zone representing extension of the crust.

D2: It is a Post-Maastrichtian event that causes a NE-directed fold-and-thrust belt in the western part of the Paikon Mt. D2 structures are NNW-SSE chevron folds.

D3: This event, although is referred for the whole Paikon zone is mostly observed and defined in the eastern part of the mountain as a transpressive event that is associated with a mylonitic fabric with the top-to-the-SW sense-of-shear and a pervasive stretching lineation which plunges consistently toward SW.

E4: This is the Neogene and Quaternary extensional event that is well observed in the whole area of Macedonia (Mercier et al. 1989, Mountrakis et al. 2006).

A significant difference of the afore-described events is that the JE2 event reported by Mercier (1968) and Vergely (1984) is not sustained by Brown and Robertson (1994). Furthermore, Sharp 
and Robertson (1993) who studied the Almopia-Paikon boundary in the area between the Theodoraki and Lakka villages mentioned only one Early Tertiary event that caused folds and thrusts with ENE-vergence.

\section{Description of map units (in the Nerostoma region)}

Our mapping in the 'Nerostoma' region, NNW of Lakka village indicates that the mapped rocks present a constant NNW-SSE trend. The larger part of the area (Fig. 2), i.e. the central and eastern one, is covered by carbonate rocks, whereas the western part is covered by NNW-SSE trending narrow strips of different lithologies. In particular, we distinguished the following map units from west to east (Fig. 2):

(a) Matrix-supported volcaniclastic rocks: They are horizontally bedded post-alpine volcaniclastic rocks formed by the volcanic activity of the Voras volcanic center that took place in PlioceneQuaternary times (Mercier 1968, Eleftheriadis 1977, Vougioukalakis 1994). They cover the uppermost parts of the NNW-SSE trending hill range with the characteristic toponym 'Korifi tou Dimitri' and rest unconformably onto the mafic volcanogenic rocks. In addition, some very small remnant exposures have been also observed as outliers on the fossiliferous limestones, but without any mapping significance.

(b) Mafic volcanogenic rocks: Mainly green-colored dolerites, laves, hydrothermally altered pink colored hyaloclastites (quartz, albite, epidote) and schistose tuffites. They are generally massive, but foliated in places, volcanogenic rocks that dip toward SW with angles $30-60^{\circ}$. They made up the NNW-SSE trending 'Korifi tou Dimitri' hill range, and on the uppermost part of this hill range, are capped by the Pliocene-Quaternary matrix-supported volcaniclastic rocks. They could be correlated with the volcanogenic rocks of the Krania Unit as the latter described by Stais (1993).

(c) Meta-pelites and radiolarites: Violet-colored, foliated, fine-grained clastic rocks, i.e., pelites interbedded with violet- or black-colored radiolarites. Within them at places, some few ochrecolored thin horizons of schistose tuffites are intercalated. In addition, some small NW-SE trending bodies of mafic volcanogenic rocks have been also observed within them. They indicate intense foliation parallel to the bedding because of the low-grade metamorphism (greenschist facies). They could be correlated with the Upper Jurassic-Lower Cretaceous deep-sea sediments of the Krania Unit.

(d) Thick-bedded to massive dark grey-colored micritic limestones: They form discontinuous lenses that outcrop along the contact between the meta-pelites to the west and the next described flysch meta-sediments to the east. They are massive- to thick-bedded, partly dolomitic, micritic limestones of bluish-grey to dark grey colour that dip as the meta-pelites and the flysch metasediments toward SSW. However, no fossils could be found into these limestones in the field.

(e) Flysch meta-sediments: Brown-colored to greenish-brown turbidites, which have been subjected to low-grade metamorphic conditions (greenschist facies) and they exhibit intense secondary foliation (Fig. 3a). They consist of poorly sorted, coarse-grained lithic sandstones, siltstones and mudstones with lenses of polymictic pebble conglomerates. Within the flysch metasediments, we have also locally observed: (a) lenses of thinly foliated pelagic limestones of pinkish-white colour and thinly foliated to laminated light beige-grey-colored marly limestones, (b) violet-colored meta-pelites similar with the previous referred map unit of meta-pelites and radiolarites, and (c) some channelized clast-supported foliated cobble conglomerates with clasts of mainly volcanic and schist rocks. They could be correlated with the Upper Jurassic-Lower Cretaceous flysch meta-sediments of the Krania Unit.

(f) Fossiliferous limestones: They are light to dark grey-colored massive- to thick-bedded neritic carbonate rocks (Fig. 3b) into which plenty of fossils have been recognized and these fossils have 


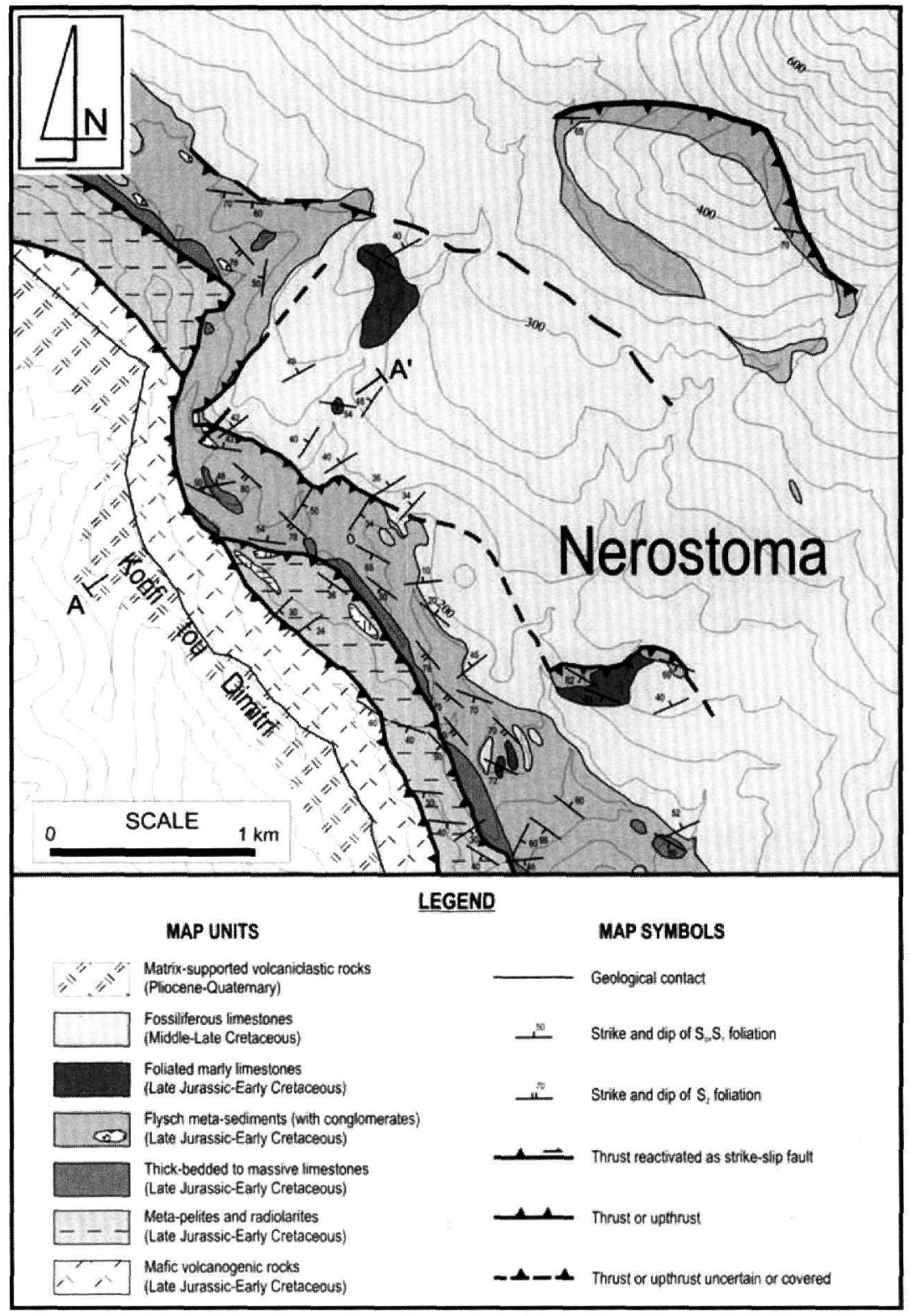

Figure 2 - Geological map of the Nerostoma, Lakka region

been already described by previous workers (Mercier 1968, Ferriere et al. 2001). They represent a carbonate platform with milliolid, peloidal and oolite-rich carbonates with local rudist-rich horizons (Sharp and Robertson 1993), which has been dated from these fossils in CenomanianTuronian. These fossiliferous carbonate rocks overlie: (a) the Upper Jurassic volcanosedimentary rocks (spilites, keratophyres), (b) the Upper Jurassic-Lower Cretaceous carbonate rocks (Kerkova Fm, Vergely et al. 2000) that outcrop more eastwards (outside the map area) in the central Paikon Mt. along the Grammos River, and south of the Kromni village the Lower Cretaceous flysch (Grammos Fm, Sharp and Robertson 1993) (Fig. 1c). Our mapping shows that these limestones also overlie unconformably the flysch meta-sediments exposed in the Nerostoma area (Fig. 3c). 

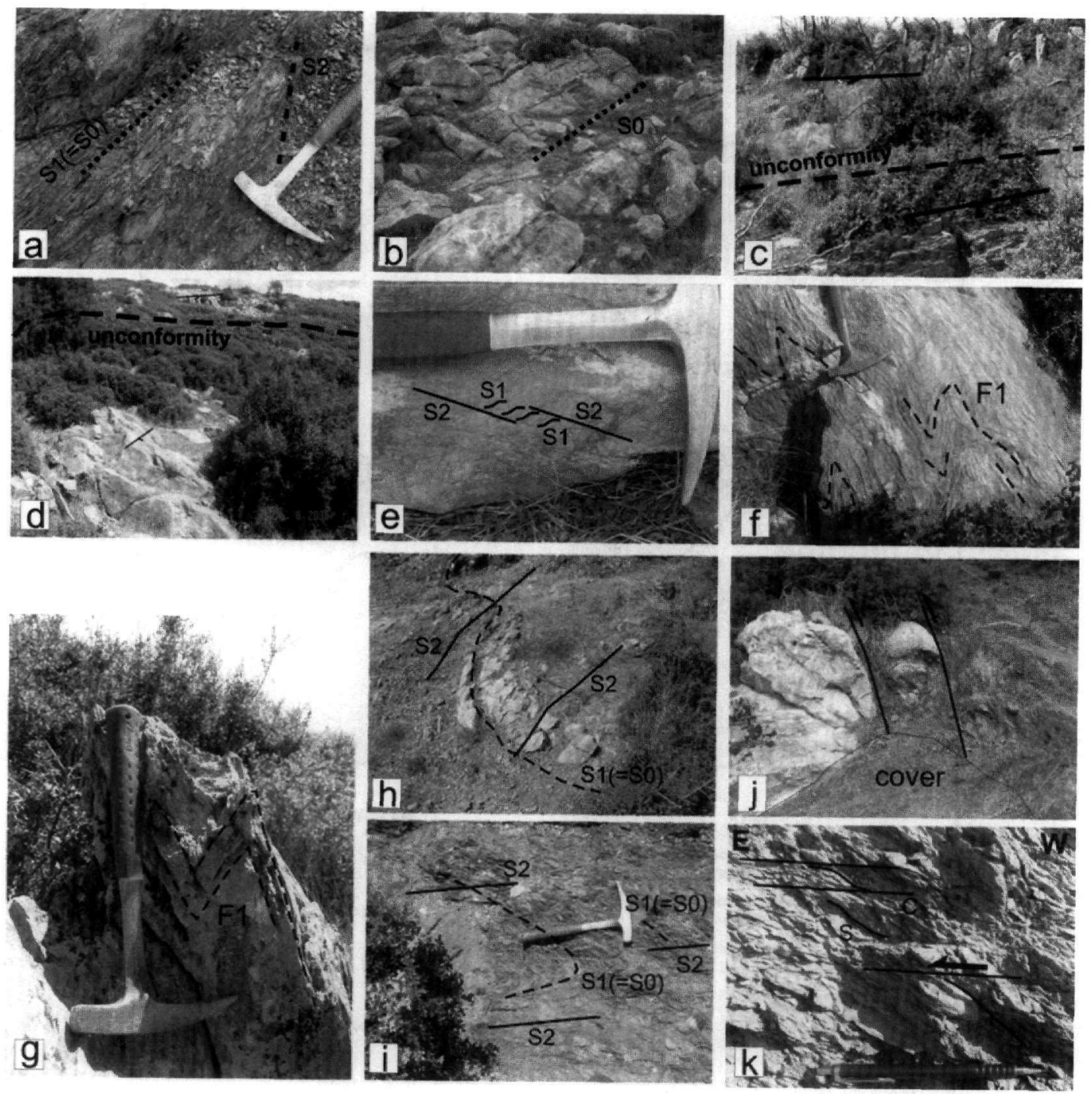

Figure 3 - Field photographs of the rocks and the structures mapped in the Nerostoma region (Lakka). (a) Flysch meta-sediments with $\mathrm{S} 1(=\mathrm{S} 0)$ and $\mathrm{S} 2$ foliation, (b) Primary region (Lakka). (a) Flysch meta-sediments with S1(=S0) and S2 foliation, (b) Prìmary foliation S0 in the Upper Cretaceous fossiliferous limestones, (c) Steeply-dipping flysch meta-sediments underlie unconformably the gently dipping toward NNW Upper Cretaceous fossiliferous limestones, (d) inlier of marly thinly foliated limestones exposed to underlie unconformably the Upper Cretaceous massive to thick-bedded fossiliferous limestones, (e) S1, S2 foliations with the limestones that interbedded the flysch meta-sediments, (f) and (g) small-scale F1folds in the limestones underneath the Upper Cretaceous fossiliferous limestones, (h) and (i) F2-folding and the S1, S2 foliations in the flysch meta-sediments, (j) Thrust contact between the flysch meta-sediments and the fossiliferous limestones, (k) S-C fabric in flysch metasediments indicating the top to the NE sense-of-shear

It is worth mentioning that within the outcrop of the fossiliferous limestones, inliers of lithologies similar with the flysch meta-sediments as well as the thinly foliated marly limestones they include 
have been found and mapped (Figs 2, 3d). The rocks of the inliers dip constantly toward SSW and underlie unconformably the fossiliferous limestones (Fig. 3d).

\section{Structural data}

\subsection{Foliation}

Apart from the post-alpine volcaniclastic rocks that present a horizontal primary foliation, i.e. bedding, the underlying alpine rocks are characterized by a no horizontal either primary or secondary foliation (Fig. 4a).

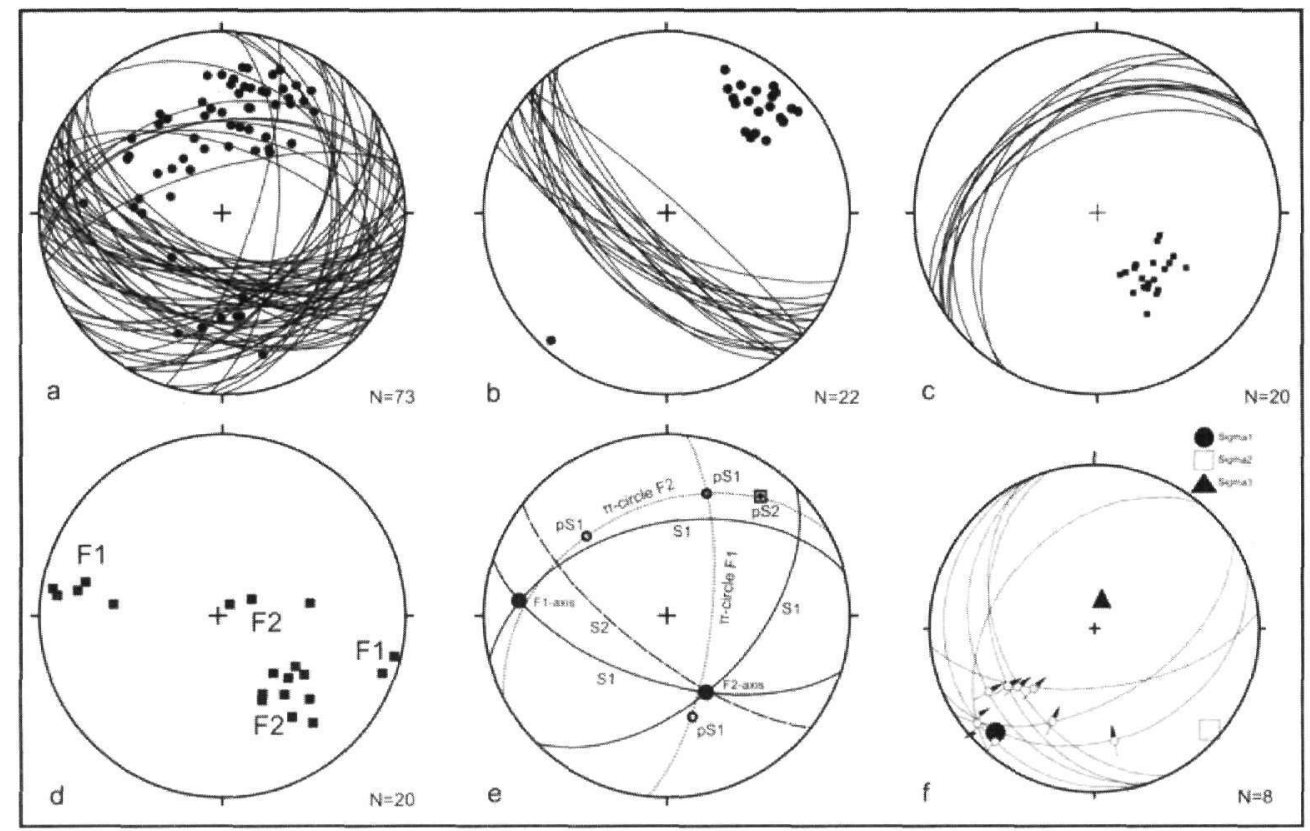

Figure 4 - Stereographic projections (lower hemisphere, equal area). (a) S0, S1 foliation of the alpine map units (fossiliferous limestones not included), (b) S2 foliation of the same map units as in (a), (c) S0 foliation of fossiliferous limestones, (d) Fold axes of mesoscopic F1 and F2 folds, (e) main structural elements of the map units (except fossiliferous limestones), (f) thrust and reverse faults in the area and the paleo-stress determination with the use of the TectonicsFP software

The dolerites are characterized by an S1 secondary foliation that dips generally toward SSW, whereas the hyaloclastites are relatively massive because of their origin (hydrothermal activity). The meta-pelites and radiolarites and the flysch meta-sediments are characterized by an S0 primary foliation which dips at medium to high angles toward SSW, and a secondary S1 foliation (slaty cleavage). The S1 foliation, is the dominant one and trends (sub)parallel to S0 dipping mainly toward SSW (Fig. 3a). A younger S2 foliation (axial plane schistosity) dips constantly toward SW (Fig. 4b) and affects the S1 and S0, forming crenulation cleavage.

It is interesting to mention that the pelagic limestones that have been found within the flyschsediments as well as the marly limestones that form inliers within the fossiliferous limestones also exhibit the above mentioned S1 and S2 secondary foliations (Fig. 3e).

In addition, an even younger S3 foliation (spaced or fracture cleavage) has been observed locally in the meta-pelites and radiolarites map unit and the thick-bedded to massive dark grey colored micritic limestones mapped between the former and the flysch meta-sediments. 
On the other hand, a not so easily observed primary foliation S0 characterizes the fossiliferous limestones; mainly the parts that are not massive (Fig. 3b). This foliation constantly dips gently $\left(\sim 30^{\circ}\right)$ toward NNW to N (Fig. $\left.4 \mathrm{c}\right)$.

\subsection{Folding}

Two main type of folding have been recognized to affect the above-mentioned alpine rocks except for the fossiliferous limestones. The first F1-folding causes WNW-ESE $\left(\sim 100^{\circ}\right)$ trending largescale, open to close, steeply inclined to inverted, asymmetric horizontal folds with vergence toward NNE (Figs 3f, g, 4d). The next F2-folding event causes asymmetric moderately plunging folds (Figs. $3 \mathrm{~h}, \mathrm{I}, 4 \mathrm{~d}$ ), i.e. the axes of these folds plunge with $\sim 30^{\circ}-40^{\circ}$ toward SE. The F2-folds, which are of metre- to decimetre-scale are smaller in size in comparison to the F1-folds. Because of the F2 folding, the large modal limb dips toward SSW, whereas the smaller modal limb dips toward $\mathrm{SE}$ to $\mathrm{E}$.

Both the F1 and F2-folds are associated with the afore-mentioned S2 axial crenulation cleavage, which in general dips at high angles $\left(\sim 70^{\circ}-80^{\circ}\right)$ toward SW. This fact indicates that the F1 and F2 folds are pene-contemporaneous with the former to precede the later. The main elements of the rocks are indicated in Fig. (4e).

\subsection{Thrusting}

As shown in the geological map (Fig. 2), most of the contacts are of tectonic nature and they are NE-directed thrusts and upthrusts. This is implied by the fact that the NW-SE trending contacts are not parallel to the S0 primary foliation and that they do not exhibit the geometrical case of a simple separation between two map units. This thrusting event has also affected the contact between the flysch meta-sediments and the fossiliferous limestones (Fig. 2). More precisely, the contact between the fossiliferous limestones and the flysch meta-sediments at many parts is a NEdirected thrust (Fig. 3j) that obliterates the previously formed stratigraphic contact of unconformity through which the fossiliferous limestones had deposited onto the flysch meta-sediments.

The analysis of the mesoscopic thrusts found in the field, with the use of the widely accepted TectonicsFP software, defines a NE-SW compression with sub-vertical least principal stress axis $(\sigma 3)$ (Fig. 4f). These faults are associated with cataclastic flow and the formation of S-C cataclastic fabric (Fig. 3k) that defines top to the NE sense-of-shear.

\section{Discussion and structural interpretation}

The 'Nerostoma' mapped area represents a complicated region where different geological interpretations have been already applied. These interpretations have direct implications on the boundary between the Almopia and Paikon zones.

The most critical issue of the geology of the area is the interpretation of the age and the relationship of the exposed rocks. Especially, to assign the correct age to the flysch metasediments and to find out the relationship of this map unit with (a) the elongate narrow limestone lenses that have been mapped along the contact with the meta-pelites and radiolarites, and (b) the fossiliferous limestones

Our geological mapping indicates the following:

(a) The exposed rocks are mafic volcanogenic rocks, pelites and radiolarites, and flysch sediments that are characterized by a low-grade (greenschist facies) metamorphism and the formation of secondary foliation.

(b) The elongate narrow limestones that have been mapped here with the map unit 'Thick-bedded to massive dark grey colored micritic limestones' are of similar appearance with the fossiliferous 
limestones. However, they do not reveal fossils in meso-scale and dip as the flysch meta-sediments, in contrast to the fossiliferous limestones that dip constantly toward NNW at gentle angles.

(b) The fossiliferous limestones cap the flysch meta-sediments as indicated by the inliers of flysch meta-sediments and/or thinly foliated marly limestones that have been mapped within the outcrop of the fossiliferous limestones and which underlie unconformably the later (Fig. 5).

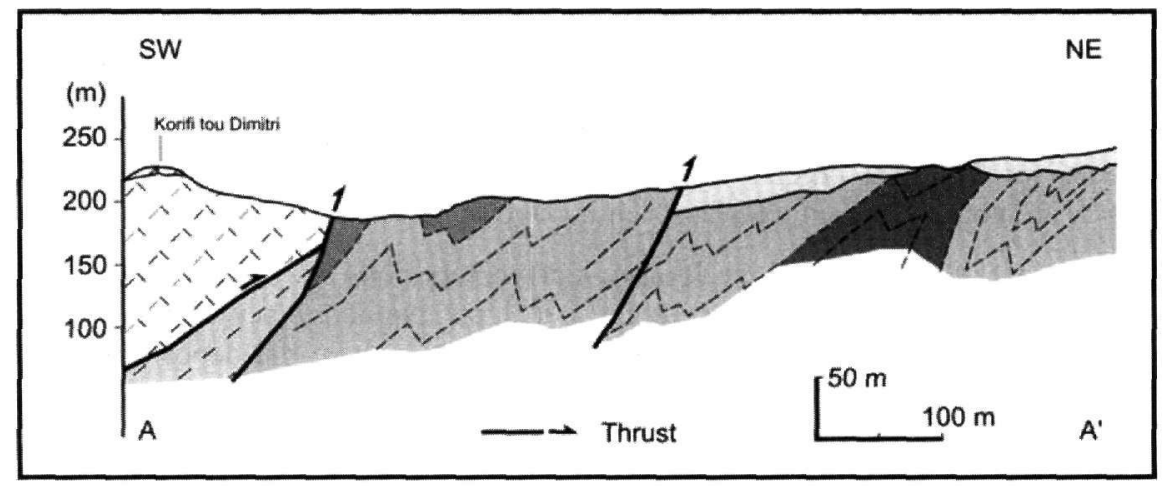

Figure 5 - Geological cross section A-A' (position and symbols as in Figure 2)

(c) The fossiliferous limestones neither exhibit any secondary foliation S1, S2 nor any F1- or F2folds.

(d) The fossiliferous limestones have been affected by NE-directed thrusts, and only because of such NE-directed thrust, we observe the flysch meta-sediments to overlie these limestones (Fig. 5).

The geological formations up to the Lower Cretaceous flysch meta-sediments have been subjected to a D1 deformation event that includes the F1- and the progressive F2-folding. This event could be correlated with the Upper Jurassic-Lower Cretaceous JE1 and JE2 event mentioned by Vergely (1984). The progressive change from the F1- to F2-folds as well as the consistent s-form geometry and the moderately plunge of the F2-folds toward SE imply that the D1 event might was related to a left-lateral oblique convergence or an inclined pure-shear dominated transpression, into which the contacts dipping toward SSW form an acute angle and not a normal one with the NE-SW contraction (assuming that the S2 foliation forms more or less normal to the maximum strain axis).

In addition, the fact that the NE-directed thrusting is recognized to all the rock units including also the Upper Cretaceous fossiliferous limestones, suggests that a D2 deformation event giving rise to the thrusting toward NE dominated the area in the Early Tertiary times as has already described by Sharp and Robertson (1993). The absence of the Upper Cretaceous carbonate rocks from the Krania Unit could be explained due to D1 deformational event and/or to D2 thrusting event.

The fact that the Upper Cretaceous fossiliferous limestones overlie unconformably the meta-flysch which is syn-metamorphosed and deformed in similar manner with the mafic volcanogenic rocks, the meta-pelites and radiolarites suggest that the later are of older age than the Late Cretaceous and therefore could be correlated with the Jurassic-Lower Cretaceous formations of the easternmost Krania Unit of the Almopia zone as the latter described by Stais (1993). They could also be correlated with the Late Jurassic-Lower Cretaceous formations of the Paikon zone exposed in the central part of the Paikon Mt. and in the eastern part of the Upper Cretaceous carbonate cover. As a result, the area seems to represent no any significant boundary between the zones of Almopia and Paikon in the Jurassic-Early Cretaceous times. Therefore, there was palaeogeographic continuity between the Paikon zone and the Krania Unit in that time. It is clear that the meta-flysch represent the most crucial formation for the paleogeographic reconstruction and since the eastern Almopian Units (Krania and Mavrolakos Units) also include this formation along with the metapelites-radiolarites and the mafic volcanogenic rocks, then the boundary between the Almopia and Paikon zones should be traced between the eastern and central Almopian Units. 


\section{Conclusions}

Our geological mapping suggests that the formations exposed in the Nerostoma-Lakka are mafic volcanogenic rocks, pelites and radiolarites and flysch sediments that are metamorphosed and deformed before the Middle-Late Cretaceous, because they are overlain unconformably by the Upper Cretaceous fossiliferous limestones. These rocks are of Late Jurassic-Early Cretaceous age and could be correlated with the formations of the eastern Almopian Units and the Upper JurassicLower Cretaceous formations exposed in the central part of the Paikon Mt. Therefore, the flysch meta-sediments are the most crucial formation for the paleogeographic reconstruction of that period and they are not of Campanian-Maastrichtian age as previously assigned.

The fact that the meta-flysch are of Late Jurassic-Early Cretaceous age and has been also found in the eastern Almopian Units (Stais 1993) suggest that the boundary between the Almopia and Paikon zones should be traced to the west of the study area, where the deposition of the flysch could be traced, that is between the eastern and western Almopian Units.

\section{References}

Brown, S., and Robertson, A., 1994. New structural evidence from the Mesozoic - Early Tertiary Paikon unit, northern Greece, Bulletin of the Geology Society of Greece, XXX/1, 159-170

Brown, S., and Robertson, A., 2003. Sedimentary geology as a key to understanding the tectonic evolution of the Mesozoic - Early Tertiary Paikon massif, Vardar suture zone, N Greece, Sedimentary Geology, 160, 179-212

Brown, S., and Robertson, A., 2004. Evidence for Neotethys rooted within the Vardar suture zone from the Voras Massif, northernmost Greece, Tectonophysics, 381, 143-173.

Eleftheriadis, G. E., 1977. Contribution to the study of the volcanogenic rocks of the South Almopia, $P h D$ thesis, University of Thessaloniki. (in Greek with English summary)

Ferriere, J., Bonneau, M., Caridroit, M., Bellier, J.P., Gorican, S., and Kollmann, H., 2001. Les nappes tertiaires du Paikon (zone du Vardar, Macédoine, Grèce): arguments stratigraphiques pour une nouvelle interprétation structurale, C. R. Acad Sci., Paris 332, 695-702.

Mercier, J., 1968. Etude géologique des zones Helleniques en Macédoine centrale (Grece), Ann. Geol. Pays Hell. 20, 792 pp.

Mercier, J-L., Simeakis, K., Sorel, D., and Vergely, P., 1989. Extensional tectonic regimes in the Aegean basins during the Cenozoic, Basin Research, 2, 49-71.

Mountrakis, D., 1979. Contribution in the knowledge of the geology of the north boundary of the Axios and Pelagonian zones in the K. Loutraki-Orma area (Almopia), PhD thesis, University of Thessaloniki. (in Greek with English summary)

Mountrakis, D., Tranos, M., Papazachos, C., Thomaidou, E., Karagianni, E., and Vamvakaris, D., 2006. Neotectonic and seismological data concerning major active faults, and the stress regimes of Northern Greece, Geological Society, London, Special Publications, 260, 649 $670,0305-8719 / 06$

Ricou, L.E., and Godfriaux, I., 1995. Mise au point sur la fenêtre multiple du Paikon et la structure du Vardar en Gréce, C. R. Acad. Sci. Paris 321 IIA, 601-608. 
Sharp, I.R., and Robertson, A.H.F., 1993. Evidence for Turonian rift-related extensional subsidence and eastward Early Tertiary thrusting, western Paikon zone. Northern Greece, Bulletin of the Geology Society of Greece, XXVIII/1, 99-100.

Sharp, I.R., and Robertson, A.H.F., 1998. Late Jurassic-lower Cretaceous oceanic crust and sediments of the easter Almopias zone, NW Macedonia (Greece); implications of the evolution of the eastern "internal" Hellenides, Bulletin of the Geology Society of Greece, $\mathrm{XXX} / 1,47-61$.

Stais, A., and Ferriére, J., 1991. Nouvelles données sur la paléogeographie Mésozoique du domaine Vardarien: Les bassins d'Almopias et de Péonias (Macedoine, Hellénides internes septentrionales), Bulletin Geology Society of Greece, XXVI/1, 491-507

Stais, A., 1993. Evolution geodynamique des bassins mesozoiques vardariens: Domaines de Péonias et d' Almopias (Hellénides internes, Macédoine centrale, Gréce), PhD thesis, University of Lille, $247 \mathrm{pp}$.

Stais, A., and Ferriére, J., 1994. Péonias (Axios-Vardar oriental; Hellenides): Donnée nouvelles sur les séries Ante-Cretacé et interprétations géodynamiques. Bulletin of the Geology Society of Greece, XXX/1, 121-132

Vergely, P., 1984. Tectoniques des ophiolites dans les Hellénides Internes (déformation, métamorphisme et phénomènes sedimentaires). Conséquences sur l' évolution des regions Téthysiennes Occidentales, PhD thesis, University Paris-Sud, Orsay.

Vergely, P., and Mercier, J., 2000. Données nouvelles sur les chevauchements d'âge post-Cretacé supérieur dans le massif du Paikon (zone de l'Axios-Vardar, Macédoine, Grèce): un nouveau modèle structural, C. R. Acad. Sci. Paris, 330, 555-561.

Vougioukalakis, G., 1994. The Pliocene volcanites of the Voras mountain, Central Macedonia, Greece. Bulletin of Geological Society of Greece, XXX/1, 223-240. 